Received: 05.05.2021; Accepted 07.05.2021; Published: 05.06.2021 at www.editoncpublishing.org

Kirimi, M. M. et. al., Editon Cons. J. Arts. Humanit. S. Stud., Double -Blind Peer Reviewed Journal

\title{
Assessment of Prosperity Gospel among Charismatic Churches in Kenya.
}

\author{
Moses M. Kirimi'; Joel Kiboss²; Peter N. Mbogo ${ }^{3}$ \\ Mount Kenya University, Kenya \\ Main author Email: kirimireginah@gmail.com
}

\begin{abstract}
The researcher sought to investigate the rise of prosperity gospel and its momentum in the midst of the learned society who can read the Bible and get its true meaning. The Equation Theory guided the study. The theory is anchored on the principle of reward and retribution, which states that the goodness of a person is confirmed by physical wellbeing and material prosperity while a sinful person is defined by the opposite. The study was carried out in Kawagware, Nairobi County that is habited by good number of people, becoming a soft target for the prosperity gospel. The study targeted congregants attending Christian charismatic churches in the area. Multi-stage sampling techniques comprising of cluster, purposive, convenient and simple random sampling procedures were used to select the churches and congregants. Data was gathered using drop and pick questionnaire for congregants. Data was analysed using SPSS (version 20) and results summarised using descriptive statistics comprising of frequencies, percentages presented using tables. Prosperity gospel was found to be appealing to congregants as it was considered to address their economic wellbeing, social wellbeing, spiritual wellbeing, guaranteeing them for holiness according, having the spiritual appeal as well as promissory prophesies. As a show of commitment, the congregants attend the churches unwaveringly, participate in the church services, and sacrifice their time, offerings, tithes, and gifts. The researcher recommends that different players, government, faith-based and private organisations should provide economic opportunities and create awareness to people living in poverty stricken areas like the Kawangware to enable them make informed decision and have economic independence.
\end{abstract}

Key Words: Appeal, Persistence, Rise of Gospel of Prosperity and Charismatic Churches $* * *$

\section{How to cite this article in APA}

Kirimi, M. M., Kiboss, J. \& Mbogo, P. N. (2021). Assessment of Prosperity Gospel among Charismatic Churches in Kenya. Editon Cons. J. Arts., Humanit. S. Stud., 3(01), 254-259.

https://doi.org/10.51317/ecjahss.v3i1.226 $* * *$ 
Editon Consortium Publishing Transforming Scholarry Publissing

\section{Editon Consortium Journal of Arts,} Humanities and Social Studies (ECJAHSS)

Doi: 10.51317/ecjahss.v3i1.226

Volume: 03 Issue: 01 |June-2021

ISSN: $2663-8525$

Received: 05.05.2021; Accepted 07.05.2021; Published: 05.06.2021 at www.editoncpublishing.org

Kirimi, M. M. et. al., Editon Cons. J. Arts. Humanit. S. Stud., Double -Blind Peer Reviewed Journal

\section{Introduction}

Kenneth Hagin who founded a thriving ministry in the 1970 s and pioneered prosperity gospel. The initial faith movements were based on positive confession, healing, and prosperity as the basic doctrines (Koch, 2009). The first doctrine, positive confession entails the hope based on the belief of receiving God's promised gifts. In readiness to receive the gifts, believers are ready and willing to let go wealth among other things perceived to be barrier to the blessings (Lioy, 2007). When some congregants confess positively, more doctrines of healing and prosperity are invoked. Salvation for Christians was considered to be granted by God graciously with no merit as it was the case of the Lutheran Doctrine (Schieman, \& Jung, 2012). It is believed that salvation for humankind was given free of charge through Jesus Christ. With the authority Jesus received from heaven, He commissioned his disciples to spread the good news of salvation and make more disciples in all nations (Hasu, 2006).

In the year 1949, there were ranks of healing evangelists that were sweeping the United States during the fifteen years that followed the Second World War (WWII) (Anderson, 2003). Over time, the ministry was transitioned to other avenues of evangelism. The leaders then initiated a radio ministry in 1966 that emphasised their evolving role as "teachers" who had begun in 1960 with the publication of the first book, redeemed from poverty, sickness and death a monthly magazine that eventually grew to a circulation of over 200,000 copies. By now, their Word-Faith theology was gaining momentum and attracting followers. To capitalise on this situation, under the leadership a man named Hagin, they launched the Rhema Bible Training Centre in Tulsa in 1974. The ministry continued to expand, compelling it in 1976 to move to a larger location in Broken Arrow, Oklahoma, a suburb of Tulsa. Here in 1985, they opened the Rhema Bible Church, which along with the Rhema Bible Training Centre developed into the axis mundi and pilgrimage centre for a global band of entrepreneurially inclined protégés and their adepts.
Kenya is a predominately-Christian country with various denominations taking the task to spread the gospel of Jesus Christ. Among these religious groupings, some have taken a direction of instant solution to the problems that humanity is undergoing. In this $21^{\text {st }}$ Century, one of the challenge and social political struggle is poverty, sickness and shelter (Hunt, 2000). The sermons are customised to prepare congregants for contributions making the churches more money oriented. These issues are the order of the sermon. The greater the 'seed', the greater is prosperity in return. Pentecostalism and charismatic oriented churches and sermons have proliferated in almost all parts of Kenya, especially major urban centres. The nature of growth and kind of sermon given is alarming.

Kawagware in Nairobi County being a residential area hosting a big number of people has become a soft target for this prosperity gospel. This study, seeks to investigate the rise of prosperity gospel, and how it has gained momentum in the midst of the learned society who can read the Bible and get its true meaning. The study investigated the source of prosperity gospel source and the power behind its popularity and sustainability. The rise of prosperity gospel has changed the testimony from Christ Jesus as Personal Saviour of the soul to material provider and instant miracle giver. The term Rise in Oxford Dictionary means to increase in amount as a level, or act of becoming more import and successful or powerful. For this study, rise means coming up, growing and gaining momentum, in the midst of learned and enlightened. Prosperity Gospel in this study refers to the doctrine of material gain and instant miracles as opposed to gospel of Christ Jesus, which is holistic in nature and eschatological in eternity hope. Therefore, study sought to explore this matter in an investigative way, with consideration of the current state of influence and source of prosperity gospel. The study concentrated in Kawangware in Nairobi County (Ongong'a, \& Akaranga, 2015). 
Editon Consortium Publishing Transforming Scholarry Publissing

\section{Editon Consortium Journal of Arts,} Humanities and Social Studies (ECJAHSS)

Doi: 10.51317/ecjahss.v3i1.226

Volume: 03 Issue: 01 June-2021

ISSN: $2663-8525$

Received: 05.05.2021; Accepted 07.05.2021; Published: 05.06.2021 at www.editoncpublishing.org

Kirimi, M. M. et. al., Editon Cons. J. Arts. Humanit. S. Stud., Double -Blind Peer Reviewed Journal

The rise of prosperity gospel has changed the testimony from Christ Jesus as Personal Saviour of the soul to material provider and instant miracle giver. With the current increase in the rate of diseases, domestic intolerance, insecurity, inflation, unemployment, business competition among other challenges affecting the living standards of believers, many have become desperate for solution of whatever manner. These prosperity gospel preachers thrive and take advantage of their followers' naivety swindling them off the little that they have purporting to offer instant solutions to their problems package inform of dramatized miracles and customised prophesies. Recently, many people led by some of the vocal mainstream religious leaders for instance, Anglican Bishop, Presbyterian Moderator and Catholic Arch Bishop, have raised concerns on the prosperity gospel seeking to get guidance and direction. Despite efforts by the registrar of society in imposing new regulations concerning churches and clergy, the prosperity gospel is relatively on the rise. There is need to understand the reasons leading to the rise this gospel despite all the sensitisation. Therefore, a paper seeks to shed more light into the matter, inform the society and Christian worshipers on dangers of this trend, and suggest recommendations on how to overcome the challenges brought about by the prosperity of gospel.

\section{METHODOLOGY}

This paper adopted descriptive research design in which the researcher aims to describe characteristics of respondents or phenomena, opinions, attitudes, preferences and perception of persons of interest to the researcher. The paper targeted at 24 churches located in Kawangware Nairobi. These churches comprised of the Christian charismatic churches and their branches built in the area meant for the residents in the area. The study targeted all the 59,430 residents of Kawangware. Data was collected using questionnaires for congregants. Questionnaires offered the advantage of being easy, cost effective and easy to analyse for a large population hence appropriate for a survey. The study is expected to yield quantitative data from the semi-structured. The researcher used Statistical Package for Social Sciences (SPSS Statistics 20).

\section{RESULTS}

Table 1: Respondents Opinion on Origin of Prosperity Gospel

\begin{tabular}{|c|c|c|c|c|c|}
\hline \multirow[b]{2}{*}{ Statement } & \multicolumn{5}{|c|}{ Percent } \\
\hline & $\begin{array}{l}\text { Strongly } \\
\text { Disagree }\end{array}$ & Disagree & Neutral & Agree & $\begin{array}{l}\text { Strongly } \\
\text { Agree }\end{array}$ \\
\hline Accessibility & 10.7 & 29.5 & 14.1 & 38.3 & 7.4 \\
\hline Background & 8.2 & 46.6 & 22.6 & 18.5 & 4.1 \\
\hline Church philosophy & 0.7 & 16.4 & 43.2 & 26.7 & 13 \\
\hline The way it was started & 10.4 & 43.1 & 21.5 & $15 \cdot 3$ & 9.7 \\
\hline The number of followers & 1.4 & 13.8 & $19 \cdot 3$ & 54.5 & 11 \\
\hline Links with the mother church & 19.5 & 36.9 & 14.8 & 21.5 & 7.4 \\
\hline
\end{tabular}

As indicated in Table 1, majority (45.7\%) of the members of charismatic churches who participated in the study stated that churches preaching prosperity gospel are accessible compared to $40.2 \%$ who stated that they are not accessible. It is also clear that majority of the members (39.7\%) stated to be in agreement with the philosophy of the charismatic churches while only $17.1 \%$ were in dispute. It was also cited by the majority (65.5\%) 
Editon Consortium Publishing

Transforming Scholarly Publissing

\section{Editon Consortium Journal of Arts,} Humanities and Social Studies (ECJAHSS)

Doi: $10.51317 /$ ecjahss.v3i1.226

Volume: 03 Issue: 01 |June-2021

ISSN: 2663-8525

Received: 05.05.2021; Accepted 07.05.2021; Published: 05.06.2021 at www.editoncpublishing.org

Kirimi, M. M. et. al., Editon Cons. J. Arts. Humanit. S. Stud., Double -Blind Peer Reviewed Journal

that the background of the charismatic churches preaching the prosperity gospel attract large number of followers. This supports the findings by Mumford (2012).

However, according to $54.8 \%$ of the members of charismatic churches that participated in the study, their loyalty to the church does not depend on its background with $22.6 \%$ citing that it does. It was also noted that majority (53.4\%) of the members were not influenced to join the charismatic churches by the way they were started with $25 \%$ stating they were influenced. Similarly, joining of the charismatic churches by $56.4 \%$ had nothing to do with their links with mother churches while $28.9 \%$ stated that it does. This contradict the findings by Alwala (2020) who attributes the rise of prosperity gospel to traditions and culture.

Table 2: Appeal of Charismatic Churches to Congregants

\begin{tabular}{|l|c|c|c|c|c|}
\hline \multirow{2}{*}{ Statement } & \multicolumn{5}{|c|}{ Percent } \\
\cline { 2 - 6 } & Strongly Disagree & Disagree & Neutral & Agree $\begin{array}{c}\text { Strongly } \\
\text { Agree }\end{array}$ \\
\hline Addresses economic wellbeing & 0.0 & 2.1 & 8.2 & 56.8 & 32.9 \\
\hline Addresses social wellbeing & 0.0 & 2.0 & 5.4 & 59.9 & 32.7 \\
\hline Addresses spiritual wellbeing & 0.0 & 1.4 & 9.5 & 56.5 & 32.7 \\
\hline Guarantees holiness & 0.7 & 3.4 & 26.7 & 29.5 & 39.7 \\
\hline Spiritually appealing & 0.0 & 2.7 & 4.8 & 43.5 & 49.0 \\
\hline Promissory prophesies & 0.0 & 1.4 & 6.8 & 25.9 & 66.0 \\
\hline
\end{tabular}

According to Table 2 the prosperity gospel preached in the sampled charismatic churches was found to be appealing, persistent and attractive to the congregants as it was considered by the majority (89.7\%) to address economic wellbeing, social wellbeing according to $92.6 \%$, spiritual wellbeing as cited by $89.2 \%$, to be a guarantee world. for holiness according to $69.2 \%$, having the spiritual appeal to $92.5 \%$ as well as promissory prophesies as postulated by $91.9 \%$. This agrees with the remarks of Mwikamba and Akaranga (2015) in the study blessed are the rich and prosperous for theirs is the Kingdom of this

Table 3: The Extent of Congregants' Persistence to Charismatic Churches

\begin{tabular}{|l|c|c|c|c|c|}
\hline \multirow{2}{*}{ Statement } & \multicolumn{5}{|c|}{ Percent } \\
\cline { 2 - 6 } & Never & Rare & Sometimes & Often & Always \\
\hline Attendance & 0.0 & 16.3 & 34.0 & 30.6 & 19.0 \\
\hline Participation in the service & 0.7 & 1.4 & 4.8 & 39.0 & 54.1 \\
\hline Time sacrifices & 0.7 & 2.1 & 19.3 & 29.0 & 49.0 \\
\hline Offerings & 0.0 & 0.7 & 8.8 & 24.5 & 66.0 \\
\hline Tithing & 1.4 & 2.1 & 10.3 & 30.1 & 56.2 \\
\hline Gift giving & 0.0 & 0.0 & 15.6 & 51.0 & 33.3 \\
\hline
\end{tabular}


Editon Consortium Publishing Transforming Scholarry Publissing

\section{Editon Consortium Journal of Arts,} Humanities and Social Studies (ECJAHSS)

Doi: $10.51317 /$ ecjahss.v3i1.226

Volume: 03 Issue: 01 |June-2021

ISSN: $2663-8525$

Received: 05.05.2021; Accepted 07.05.2021; Published: 05.06.2021 at www.editoncpublishing.org

Kirimi, M. M. et. al., Editon Cons. J. Arts. Humanit. S. Stud., Double -Blind Peer Reviewed Journal

According to Table 3, it was established that the members of the charismatic church congregations are persistent in their attendance as indicated by $49.6 \%$, participating in the church services as cited by $93.1 \%$, sacrificing their time according to $78 \%$, giving offerings by $90.5 \%$, tithing as cited $86.3 \%$ as well as giving of gifts according to $84.3 \%$. This agrees with Ongong'a and Akaranga (2015) that the congregants participate in prosperity gospel in Kenyan especially in the urban centres as they are convinced to come, see, pay and receive your miracles and healing.

\section{CONCLUSION AND RECOMMENDATIONS}

The study revealed that members of charismatic churches who participated in the study stated that churches preaching prosperity gospel are accessible compared. It is also found that members are in agreement with the philosophy of the charismatic churches. The background of the charismatic churches preaching the prosperity gospel was considered to attract large number of followers. Members of charismatic churches stated that their loyalty to the church does not depend on its background. Members stated that they were not influenced to join the charismatic churches by the way they were started. Similarly, joining of the charismatic churches for members had nothing to do with their links with mother churches.

From the study findings, the researcher was able to conclude that the prosperity gospel preached in charismatic church is growing and rising rapidly in the developing countries. The growth is characterised by the ability of the charismatic churches making prosperity gospel appealing to congregants in terms of addressing their economic wellbeing, social wellbeing, spiritual wellbeing, guaranteeing them for holiness according, having the spiritual appeal as well as promissory prophesies.

From the study, it is evident that prosperity gospel is on the rise and growing as the members of the charismatic churches where the charismatic gospel is preached was found to be committed to the gospel. Their commitment is manifested in form of unceasing attendance, participation in the church services, sacrificing their time, offerings and tithing as well as giving of gifts. This leaves their followers in a worse state since the little amounts that they had before has been taken away from them instead of making good use of it so as to reduce their poor situation. As for the sake of those having health challenges, some go to the extent of discarding their medication worsening their conditions and in some cases causing fatalities. For those who have social problems, their minds are filled with ideal doctrines that is contrary to the reality attributed to a paradigm shift in which they regard to those they ought to reconcile with as demons thus creating a hostile environment.

There is need for community outreach to the residents of informal settlement schemes to create awareness on the forms and matters pertaining to prosperity gospel. This will give them the necessary information that will enable them make informed decisions when joining the charismatic churches and not to be influenced by peer pressure, social status, and family when choosing a church. This will shield them from being gullible and fall prey to the preachers of prosperity gospel who exploit their socio-cultural weakness. Preachers of the word should teach the gospel of Christ without manipulating and bending towards prosperity gospel with the aim of twisting the minds and exploiting their followers. True gospel is supposed to set people free rather than exposing them to spiritual bondage where the followers are exposed to suffering at the expense of prosperity gospel that benefits the preachers. 


\section{Editon Consortium Journal of Arts, Humanities and Social Studies (ECJAHSS)}

Doi: $10.51317 /$ ecjahss.v3i1.226

Volume: 03 Issue: 01 |June-2021

ISSN: $2663-8525$

Received: 05.05.2021; Accepted 07.05.2021; Published: 05.06.2021 at www.editoncpublishing.org

Kirimi, M. M. et. al., Editon Cons. J. Arts. Humanit. S. Stud., Double -Blind Peer Reviewed Journal

\section{References}

Alwala, B. (2020). The fate of prosperity gospel in Kenya. East African Journal of Traditions, Culture and Religion, 2(1), 13-22.

Anderson, A. (2003). The contribution of David Yonggi Cho to a contextual theology in Korea. Journal of Pentecostal Theology, 12(1), 85-105.

Hasu, P. (2006). World Bank \& heavenly bank in poverty \& prosperity: the case of Tanzanian faith gospel. Review of African Political Economy, 33(110), 679-692.

Hunt, S. (2000). 'Winning ways': Globalisation and the impact of the health and wealth gospel. Journal of Contemporary Religion, 15(3), 331-347.

Koch, B. A. (2009). The prosperity gospel and economic prosperity: Race, class, giving, and voting. (Doctoral dissertation), Indiana University.

Lioy, D. (2007). The heart of the prosperity gospel: Self or the saviour? Conspectus: The Journal of the South African Theological Seminary, 4(09), 41-64.

Mumford, D. J. (2012). Prosperity gospel and African American prophetic preaching. Review \& Expositor, 109(3), 365-385.

Mwikamba, C., \& Akaranga, S. I. (2015). Blessed are the rich and prosperous for theirs is the Kingdom of this world: The Kenyan Challenge. Research on Humanities and Social Sciences, 5(14), 138-141.

Ongong'a, J. J., \& Akaranga, S. I. (2015). Prosperity gospel in Kenyan urban centres: Come, see, pay and receive your miracles and healing. Research on Humanities and Social Sciences, 5(10), 199-208.

Schieman, S., \& Jung, J. H. (2012). "Practical divine influence": Socioeconomic status and belief in the prosperity gospel. Journal for the Scientific Study of Religion, 51(4), 738-756. 